\title{
COMPARATIVE STUDY BETWEEN RAW AND COOKED FISH SOLD IN ASSIUT CITY ON THE INCIDENCE OF SOME FOODBORNE PATHOGENS
}

\author{
GHADA MAHAMED MOHAMED
}

Animal Health Research Institute, Assiut Regional Laboratory.

\begin{tabular}{|c|c|}
\hline & ABSTRACT \\
\hline Received at: $25 / 3 / 2012$ & $\begin{array}{l}\text { The present investigation was carried on } 90 \text { random samples } \\
\text { ( } 30 \text { of each) or raw and } 60 \text { cooked (grilled and fried,each } 30 \text { ) } \\
\text { fish which obtained from different fish market and restaurants } \\
\text { in Assiut city. These samples were examined bacteriologically } \\
\text { by standard procedures for determination of Aerobic plate } \\
\text { count, and counts of coliform, faecal coliform, E.coli and Staph } \\
\text { aureus where the mean values of these microorganisms in raw } \\
\text { fish were: } 44.6 \times 10^{5} \pm 22.7 \times 10^{5}, 56.6 \times 10 \pm 7.6 \times 10,0.8 \times \\
10 \pm 0.1 \times 10,0.7 \times 10 \pm 0.1 \times 10 \text { and } 32.8 \times 10 \pm 14.9 \times 10 / g \\
\text { respectively. Wherease the corresponding mean values of } \\
\text { grilled fish were: } 22.3 \times 10^{5} \pm 5.6 \times 10^{5}, 48 \times 10 \pm 7.6 \times 10,0.6 \\
\times 10 \pm 0.08 \times 10,0.7 \times 10 \pm 0.2 \times 10 \text { and } 21.5 \times 10 \pm 12.9 \times 10 / g \\
\text { respectively. While the mean values in fried fish were: } 2.1 \times \\
105 \pm 0.7 \times 10^{5}, 19.7 \times 10 \pm 6.7 \times 10,0.4 \times 10 \pm 0.05 \times 10,0.5 \times \\
10 \pm 0.2 \times 10 \text { and } 5.5 \times 10 \pm 3.5 \times 10 / \mathrm{g} \text { respectively. Some } \\
\text { foodborne pathogens as E.coli, Staph aureus C.perfrengens, } \\
\text { Listeria monocytogenes and Aeromonas spp, could be isolated } \\
\text { from raw fish in incidence of } 13.3,30,46.7,10 \text { and } 73.3 \% \\
\text { respectively while that in grilled fish was } 16.7,20,20,6.7 \text { and } \\
40 \% \text { respectively. As for fried fish the incidence was } 6.7,13.3 \text {, } \\
10,10 \text { and } 30 \% \text { respectively. Samonella failed to be recovered } \\
\text { from all examined samples. The public health importance of the } \\
\text { recovered microorganisms as well as some recommended } \\
\text { measures for improving the quality of such products were } \\
\text { discussed. }\end{array}$ \\
\hline
\end{tabular}

Key words: Raw fish, cooked fish, fish market, food borne pathogen.

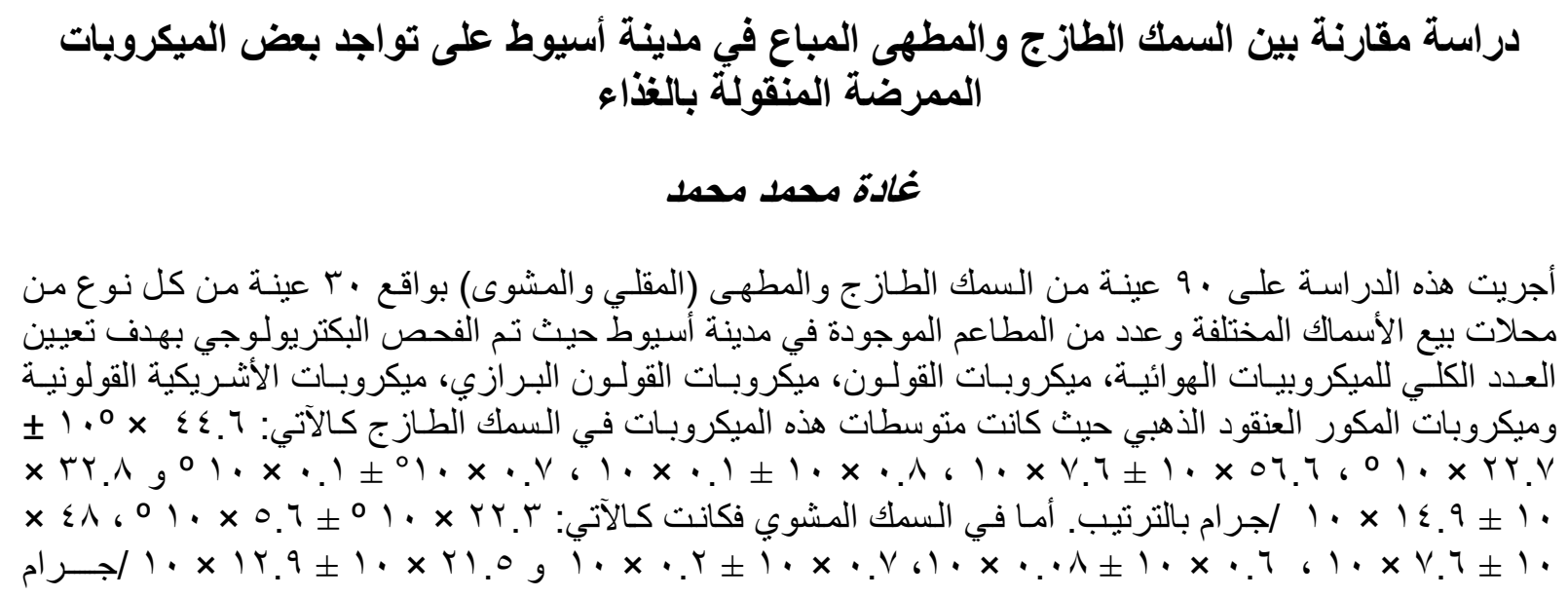




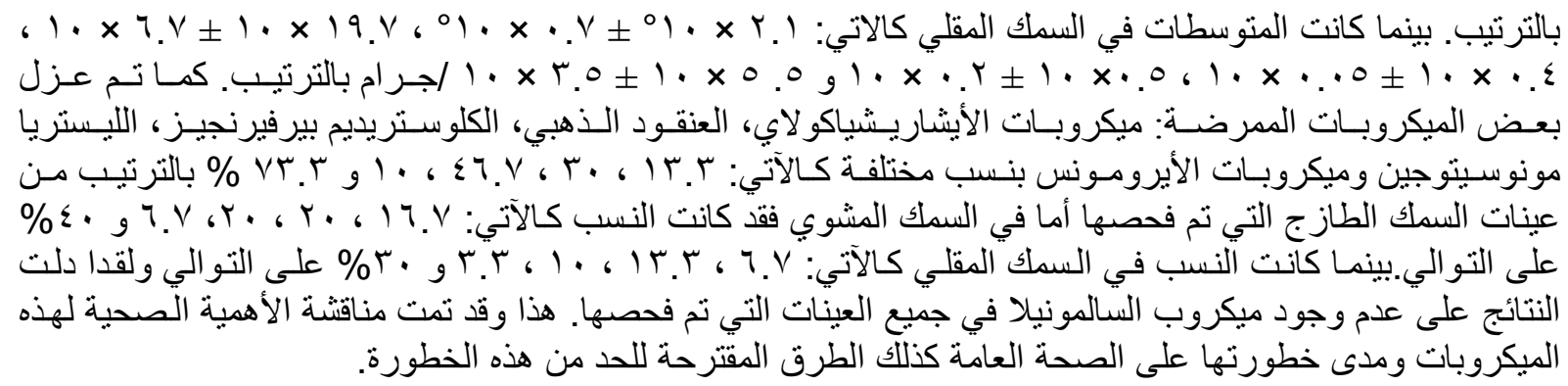

\section{INTRODUCTION}

Fish are very important source of protein specially in Egypt where animal protein is insufficient to meat the requirements of the population. They have long been regarded as nutritive and highly desirable food due to its contribution of high quality animal protein, its exceptional riches in calcium and phosphorus and its generous supply of B-complex (Mutkoski and Schurer, 1981).

Quality of fish is often more difficult to control due to variations in species, sex, age, habitats and action of autolytic enzymes as well hydrolytic enzymes of microorganisms on the fish muscle (Venugopol, 2002). Safety of ready-to-eat fish meals with reference to bacterial contamination is usually concerned with possibility of the food infection and intoxication.

In general, when a healthy fish is caught, the fish is sterile as its immune system prevents bacteria to proliferate easily whereas after death the fish's immune system collapses allowing easly penetration of microorganisms into the flesh (Huss, 1995). This peneteration increase in case of fish caught from polluted area where there are high densities of bacteria (Howgate, 1998). So, that many investigators convinced that fish from polluted environment may be passive carriers of bacteria pathogenic to man (Varnam and Evans, 1991).

Furthermore, pathogenic bacteria are naturally present in aquatic environment (Clostridium, Aeromonas) and the general environment (L.monocytogenes). Other microorganisms are of animal / human reservoir (Salmonella, E. coli), thus there is always a possibility that these microorganisms may be passed on to the raw material during production and processing (Huss et al., 2000).

Contamination is a very important aspect as this is the mode that most unwanted microorganisms may be transmitted onto seafood and other products. These unwanted microorganisms may access food processing environments through raw materials, personel or mobile equipment or through pests and some pathogens may even become established in the processing plant and from niches where they can survive for long periods of time (Reij et al., 2003). Transfer of microorganisms by personnel particulary from hands, is of vital importance (Chen et al., 2001, Montville et al., 2001; Bloom field, 2003). During handling and preparation, bacteria are transferred from contaminated hands of food workers to food and subsequently to other surfaces (Montville et al., 2002). Water is also a vehicle for transmission of may agents of diseases (Kirby et al., 2003).

The degree of cooking employed further effects on the number and the types of microorganisms. Moreover, organisms normally associated with raw fish are not heat resistant and are destroyed during heat process. Heat resistant types of organisms may be introduced with spices or other ingredients (Nickelson and Finne, 1984). Therefore morphological quality as well as sources of contamination of such meals have been studied by many researchers.

The purpose of this investigation was to determine the bacteriological status (aerobic count, coliforms, faecal coliforms, E.coli, Staph aureus, Aeromonas spp. Salmonella spp., Listeria monocytogenes and Clostridium perfringens) of raw and cooked (fried and 
grilled) fish and monitoing the public health importance of the isolated organisms as well as some of the recommended measures for improving the quality of such products.

\section{MATERIALS and METHODS}

\section{Collection of samples:}

A total of 90 random samples of fish represented by 30 raw freshwater and 60 ready-to-eat (grilled and fried, each 30) fish were collected from fish markets and restaurants with different sanitation levels in Assiut city. All the collected samples were then transferred to the laboratory under complete aseptic conditions without undue delay where they were prepared and examined.

\section{Sampling (Scott et al., 1992):}

Flesh samples were taken from the left hand side of each fish in the anterior dorsal region. For raw fish, the skin was rinsed with $95 \%$ ethanol and flamed. For all collected samples, the skin was removed and the underlying flesh was aseptically transferred into a clean separate sterile mortar. Each sample was mixed well then prepared for bacteriological examination:

\section{Preparation of samples:}

To $25 \mathrm{gm}$ of each samples, $225 \mathrm{ml}$ of sterile $0.1 \%$ peptone water were added and thoroughly mixed using sterile blender for approximately 2 min.to obtain a dilution of $1 / 10$, then decimal dilutions were prepared as recommended by APHA (1992). The prepared dilutions and samples were subjected to the following examinations:

\section{A-Enumeration procedures:}

1- Aerobic plate count (APC): The technique recommended by APHA (1992) using surface plating method was used.

2- Colifrom, faecal coliform and E.coli count (MPN/g): According to the technique out lined by AOAC (1990).

3- Staph aureus count: The surface plating technique of Baird -Parker ager plates as described by APHA (1992) was followed.

\section{B- Isolation procedures:}

1-Detection of Salmonella spp:According to the method recorded byAPHA (1992).

2-Isolation of Listeria spp.:The technique recommended by Grey and killinger 1966.

3-Isolation of Clostridium perfringens:This was done according to the technique adopted by Angeloti et al. (1967).

4- Isolation of Aeromonas spp.:The technique was done as described by Okrend et al. (1987), and Ahmed et al. (1991).

5- Isolation of Staph.aureas:Was carried out using Mannitol Salt agar as recommended by Feingold and Martin (1982).

\section{RESULTS}

Table 1: Statistical values of aerobic plate count/gm of the examined raw, grilled and fried fish samples $(\mathrm{n}=30$ of each).

\begin{tabular}{lccccccc}
\hline $\begin{array}{l}\text { Types of } \\
\text { samples }\end{array}$ & \multicolumn{2}{c}{ Positive samples } & Minimum & Maximum & Mean & SE & P. value \\
\cline { 2 - 6 } Ro & $\%$ & & & & & \\
\hline Raw fish & 30 & 100 & $88 \times 10^{3}$ & $52 \times 10^{6}$ & $44.6 \times 10^{5}$ & $22.7 \times 10^{5}$ & $\begin{array}{c}<0.001 \\
* * *\end{array}$ \\
\hline Grilled fish & 30 & 100 & $25 \times 10^{3}$ & $93 \times 10^{5}$ & $22.3 \times 10^{5}$ & $5.6 \times 10^{5}$ & $\begin{array}{c}<0.001 \\
* * *\end{array}$ \\
\hline Fried fish & 30 & 100 & $22 \times 10^{3}$ & $7 \times 10^{5}$ & $2.1 \times 10^{5}$ & $0.7 \times 10^{5}$ & N.S \\
\hline
\end{tabular}


Table 2: Statistical values of coliform count (MPN/gm) of the examined raw, grilled and fried fish samples $(n=30$ of each).

\begin{tabular}{lccccccc}
\hline \multirow{2}{*}{$\begin{array}{l}\text { Types of } \\
\text { samples }\end{array}$} & \multicolumn{2}{c}{ Positive samples } & Minimum & Maximum & Mean & SE & P. value \\
\cline { 2 - 4 } No & $\%$ & & & & \\
\hline Raw fish & 30 & 100 & $2.1 \times 10^{2}$ & $1.1 \times 10^{3}$ & $56.6 \times 10$ & $7.6 \times 10$ & $\begin{array}{c}<0.001 \\
* * *\end{array}$ \\
\hline Grilled fish & 30 & 100 & $1.5 \times 10^{2}$ & $1.1 \times 10^{3}$ & $48 \times 10$ & $7.6 \times 10$ & $\begin{array}{c}<0.001 \\
* * *\end{array}$ \\
\hline Fried fish & 30 & 100 & 9.1 & $1.1 \times 10^{3}$ & $19.7 \times 10$ & $6.7 \times 10$ & N.S \\
\hline
\end{tabular}

Table 3: Statistical values of coliform count (MPN/gm) of the examined raw, grilled and fried fish samples $(\mathrm{n}=30$ of each).

\begin{tabular}{|c|c|c|c|c|c|c|c|}
\hline \multirow{2}{*}{$\begin{array}{l}\text { Types of } \\
\text { samples }\end{array}$} & \multicolumn{2}{|c|}{ Positive sample } & \multirow{2}{*}{ Minimum } & \multirow{2}{*}{ Maximum } & \multirow{2}{*}{ Mean } & \multirow{2}{*}{$\mathrm{SE}$} & \multirow{2}{*}{ P. value } \\
\hline & No & $\%$ & & & & & \\
\hline Raw fish & 28 & 93.3 & 3 & $1.5 \times 10$ & $0.8 \times 10$ & $0.1 \times 10$ & $\begin{array}{c}<0.001 \\
* * *\end{array}$ \\
\hline Grilled fish & 26 & 86.7 & 3 & $1.5 \times 10$ & $0.6 \times 10$ & $0.08 \times 10$ & $<0.05^{*}$ \\
\hline Fried fish & 21 & 70 & 3 & 7.3 & $0.4 \times 10$ & $0.05 \times 10$ & N.S \\
\hline
\end{tabular}

Table 4: Statistical values of E.coli count (MPN/gm) of the examined raw, grilled and fried fish samples $(\mathrm{n}=30$ of each).

\begin{tabular}{|c|c|c|c|c|c|c|c|}
\hline \multirow{2}{*}{$\begin{array}{l}\text { Types of } \\
\text { samples }\end{array}$} & \multicolumn{2}{|c|}{ Positive samples } & \multirow{2}{*}{ Minimum } & \multirow{2}{*}{ Maximum } & \multirow{2}{*}{ Mean } & \multirow{2}{*}{ SE } & \multirow{2}{*}{ P. value } \\
\hline & No & $\%$ & & & & & \\
\hline Raw fish & 4 & 13.3 & 7.3 & 20 & $0.7 \times 10$ & $0.1 \times 10$ & N.S \\
\hline Grilled fish & 5 & 16.7 & 3.6 & 14 & $0.7 \times 10$ & $0.2 \times 10$ & N.S \\
\hline Fried fish & 2 & 6.7 & 3.6 & 7.3 & $0.5 \times 10$ & $0.2 \times 10$ & N.S \\
\hline
\end{tabular}

Table 5: Statistical values of Staph aureus count / gm of the examined raw, grilled and fried 
fish samples ( $\mathrm{n}=30$ of each).

\begin{tabular}{lccccccc}
\hline $\begin{array}{l}\text { Types of } \\
\text { samples }\end{array}$ & \multicolumn{2}{c}{ Positive samples } & Minimum & Maximum & Mean & SE & P. value \\
\cline { 2 - 7 } & No & $\%$ & & & & & \\
\hline Raw fish & 6 & 20 & $8 \times 10$ & $1 \times 10^{3}$ & $32.8 \times 10$ & $14.9 \times 10$ & N.S \\
\hline Grilled fish & 4 & 13.3 & $5 \times 10$ & $6 \times 10^{2}$ & $21.5 \times 10$ & $12.9 \times 10$ & N.S \\
\hline Fried fish & 2 & 6.7 & $2 \times 10$ & $9 \times 10$ & $5.5 \times 10$ & $3.5 \times 10$ & N.S \\
\hline
\end{tabular}

N.S.:Non significant $\quad *$ : significant $\quad * *$ :moderatly significant $\quad * * *$ :highly significant

Table 6: Incidence of the isolated microorganisms from the examined raw, grilled and fried fish samples.

\begin{tabular}{|c|c|c|c|c|c|c|c|c|}
\hline \multirow{3}{*}{ Organisms } & \multicolumn{6}{|c|}{ Type of Samples } & \multirow{2}{*}{\multicolumn{2}{|c|}{ Total }} \\
\hline & \multicolumn{2}{|c|}{ Raw fish } & \multicolumn{2}{|c|}{ Grilled fish } & \multicolumn{2}{|c|}{ Fried fish } & & \\
\hline & $\mathrm{N} / 30$ & $\%$ & $\mathrm{~N} / 30$ & $\%$ & $\mathrm{~N} / 30$ & $\%$ & $N / 30$ & $\%$ \\
\hline E.coli & 4 & 13.3 & 5 & 16.7 & 2 & 6.7 & 11 & 12.2 \\
\hline Staph aureus & 9 & 30 & 6 & 20 & 4 & 13.3 & 19 & 21.1 \\
\hline C.perfringens & 14 & 46.7 & 6 & 20 & 3 & 10 & 23 & 25.6 \\
\hline Listeria $\mathrm{spp}$ & 8 & 26.7 & 5 & 16.7 & 3 & 10 & 16 & 17.8 \\
\hline L.monocytogenes & 3 & 10 & 2 & 6.7 & 1 & 3.3 & 6 & 6.7 \\
\hline Aeromonas spp & 22 & 73.3 & 12 & 40 & 9 & 30 & 43 & 47.8 \\
\hline A.hydrophila & 12 & 40 & 6 & 20 & 3 & 10 & 21 & 23.3 \\
\hline A.caviae & 7 & 23.3 & 4 & 13.3 & 5 & 16.7 & 16 & 17.8 \\
\hline A.sorbia & 3 & 10 & 2 & 6.7 & 1 & 3.3 & 6 & 6.7 \\
\hline Salmonella spp & 0 & 0 & 0 & 0 & 0 & 0 & 0 & 0 \\
\hline
\end{tabular}

\section{DISCUSSION}

From the summarized results given in Table 1 it is evident that all the examined raw, grilled and fried fish samples (100\%) contained viable bacteria. In raw fish, the aerobic plate count (APC) varied from $88 \times 10^{3}$ to $52 \times 10^{6}$ with a mean value of $44.6 \times 10^{5} \pm 22.7 \times 10^{5}$ $\mathrm{cfu} / \mathrm{gm}$ while that of grilled fish ranged from $25 \times 10^{3}$ to $93 \times 10^{5}$ with a mean value of 22.3 $\times 10^{5} \pm 5.6 \times 10^{5} \mathrm{cfu} / \mathrm{gm} /$. As for fried fish, their mean APC was $2.1 \times 10^{5} \pm 0.7 \times 10^{5}$ $\mathrm{cfu} / \mathrm{gm}$ with a minimum of $22 \times 10^{2}$ and a maximum of $7 \times 10^{5}$.

Correlation between the aerobic plate count and types of fish samples examined recorded in Table 1 revealed that there was a high significant difference in the mean aerobic plate count between each of raw, grilled and fried fish samples.

Lower counts of aerobic bacteria were enumerated in raw fish by Surkewicz et al. (1968), Thabet (1972), Farouk (1989) and Mahmoud (1999) who recorded an average values of $2.5 \times 10^{4}, 15 \times 10^{2}, 10^{4}$ and $3 \times 10^{3}$ cfu/gm, respectively. On the other hand Yousef et al. (1985) and Morshidy (1992 a) reported higher counts represented by a mean values of $78.7 \times 10^{5}$ and $10 \times 10^{6} \mathrm{cful} / \mathrm{gm}$ raw fish. As for ready - to- eat fish, Hefnawy (1990) cited a mean APC of $22.2 \times 10^{2} / \mathrm{gm}$ of fried fish which seem to be lower than the obtained results whereas Eldaly and Ibrahim (1987) reported higher mean APC which 
were $2 \times 10^{6}$ and $9 \times 10^{6} \mathrm{cfu} / \mathrm{gm}$ of the examined grilled and fried fish respectively.

However, fish and shellfish of good quality will have counts less than $1 \times 10^{5} / \mathrm{gm}$ of tissue at $20^{\circ} \mathrm{C}$. High counts should be considered an evidence of a potentially hazardous situation (FAO, 1992).

Coliforms as recorded in Table 2 were existed in all the examined $(100 \%)$ raw fish samples in number varied from $2.1 \times 10^{2}$ to $1.1 \times 10^{3}$ with a mean MPN value of $56.6 \times 10 \pm 7.6 \times$ $10 / \mathrm{gm}$. In this respect Surkewicz et al. (1968) reported that the MPN of coliforms was less than $10 / \mathrm{gm}$ raw fish, in addition lower coliform counts were recorded by Farouk (1989) and El-Sayed (1991) who reported an average MPN value of 30 and $2.5 \times 10 / \mathrm{gm}$, respectively. On the other hand, higher findings $\left(4.47 \times 10^{4}, 14 \times 10^{3}, 5.8 \times 10^{2}\right.$, $4.47 \times 10^{4}$ and $\left.6.6 \times 10^{3} / \mathrm{gm}\right)$ were reported by Morshidy and Hafez (1986), Abdel -Galil et al. (1988), Naser (1991), Morshidy (1992b) and Mahmoud (1999), respectively.

Regarding ready-to-eat fish, all the examined samples $(100 \%)$ had coliforms where the level of contamination in grilled fish ranged from $1.5 \times 10^{2}$ to $1.1 \times 10^{3}$ with a mean MPN value of $48 \times 10 \pm 7.6 \times 10 / \mathrm{gm}$ whereas fried fish contained coliforms at a level varied from 9.1 to $1.1 \times 10^{3}$ with a mean MPN value of $19.7 \times 10 \pm 6.7$ x 10/gm. Eldaly and Ibrahim (1987) recorded a mean coliform count of $2 \times 10^{4}$ and $6 \times 10^{2} / \mathrm{gm}$ of grilled and fried fish samples examined, respectively, However, a high significant difference in the mean MPN of coliforms could be detected between raw and fried fish as well as between grilled fish and fried ones (Table 2).

Furthermore, in table 3 faecal coliforms were detected in the examined raw and ready-to-eat fish samples. Majority (93.3\%) of the positive raw fish samples were contaminated with these organisms in counts ranged from 3 to $1.5 \times 10$ with a mean MPN value of $0.8 \times 10$ $\pm 0.1 \times 10 / \mathrm{gm}$. Moreover, 86.7 and $70 \%$ of the examined grilled and fried fish samples had a mean MPM values of $0.6 \times 10 \pm 0.08 \times$ 10 and $0.4 \times 10 \pm 0.05 \times 10 / \mathrm{gm}$ with minimum of 3 and 3 and a maximum of $1.4 \mathrm{x}$ 10 and $7.3 \times 10 / \mathrm{gm}$, respectively. A highly significant difference in the mean MPN of faecal coliforms was noticed between raw and fired fish and this variation was significant between grilled and fried fish.

The presence of coliforms in food indicates a potable faecal source of contamination. Their significance in food deponds upon the circumstances to with the food has been exposed and their presence in great number may raise the public health hazard (National Academy of Sciences 1995).

As for E.coli, Table 4 verify that $13.3,16.7$ and $6.7 \%$ of the examined raw, grilled and fried fish samples contained variable numberS where their MPN values were $0.7 \mathrm{x}$ $10 \pm 0.1 \times 10,0.7 \times 10 \pm 0.2 \times 10$ and $0.5 \times 10$ $\pm 0.2 \times 10 / \mathrm{gm}$, respectively. Most of the examined fish samples had MPN was $<3 / \mathrm{gm}$. No significant difference in the mean MPN of E.coli was noticed between the three examined fish samples. Eldaly and Ibrahim (1987) recorded a mean MPN values of $2 \times 10^{2}$ and $48 / \mathrm{gm}$ of the examined grilled and fired fish which seem to be higher than that obtained in the present study.

The findings outlined in Table 5 declared that Staph aureus was existed in variable numbers in $20,13.3$ and $6.7 \%$ of the examined raw, grilled and fired fish samples respectively whereas the remainder of the samples contained non detectable levels. The mean Staph aureus count values were $32.8 \times 10$ $\pm 14.9 \times 10,21.5 \times 10 \pm 12.9 \times 10$ and $5.5 \times 10$ $\pm 3.5 \times 10 \mathrm{cfu} / \mathrm{gm}$ raw, grilled and fired fish samples respectively with non significant difference between such means.

However, Morshidy and Hafez (1986), Hafez (1989), Naser (1991), Morshidy (1992a, b) recorded higher Staph aureus counts than the results of this investigation for raw fish where the mean figures were $4.8 \times 10^{2}, 12.33 \times 10^{2}$, $1.3 \times 10^{3}, 9.5 \times 10^{6}$ and $4.8 \times 10^{2} \mathrm{cfu} / \mathrm{gm}$, respectively. Also, higher counts were recorded for fried fish by Adesiyun (1983) $\left(2.6 \times 10^{6}\right)$, Eldaly and Ibrahim (1987) $(4.75 \times$ $\left.10^{3}\right)$ and Hefnawy (1990) $\left(4 \times 10^{2}\right)$ whereas the mean Staph aureus count/gm grilled fish was $6 \times 10^{2} \mathrm{cfu} / \mathrm{gm}$ as reported by Eldaly and Ibrahim (1987).

According to the results presented in Table 6, 
it is evident that different microorganisms could be isolated in variant percentages from the examined 90 raw and ready-to- eat fish samples. These organisms were identified as E.coli (12.2\%), Staph. aureus (21.1\%), C.perfrirgens (25.6\%), Listeria spp. (17.8\%) of which L.monocytogenes constituted 6.7\%, Aeromonas spp (47.8\%), where the identified strains were A.hydrophila (23.3\%), A. caviae (17.8\%) and A.Sorbia (6.7\%). On the other hand Salmonella organisms failed to be detected in any of the examined raw, grilled or fried fish samples.

Regarding E.coli., the findings illustrated in table 6 revealed that $13.3,16.7$ and $6-7 \%$ of the examined raw, grilled and fried fish samples proved to harbour E.coli. However, Yousef et al. (1981), Yousef et al. (1985), Mahmoud (1999), El-Gohary and Samaha (1992), and Morshidy (1992 b) reported the isolation of E.coli from 7.92, 1.98, 6, 1.7 and $14 \%$ of raw fish while its recovery rate from fried fish was $12 \%$ as recorded by Hefnawy (1990).

It is clearly evident from the mentioned results in Table 6 that 30,20 and $13.3 \%$ of the examined raw, grilled and fired fish samples contained Staph aureus Hefnawy, (1990) recorded that the incidence of Staph aureus was $20 \%$ in fired fish with was higher than that abtained in this study.

Small number of Staph aureus don't assure safety because it can produce enterotoxin and die during storage and processing but toxin remain in food (National Academy of Sciences, 1995).

As for C.perfringens in Table 6 it was existed in $46.7,20$ and $10 \%$ of the examined raw, grilled and fried fish samples respectively. Abd El-Rahman et al. (1989) were able to isolate C.perfringens from $10 \%$ of the examined raw fish samples.

However, Hefnawy (1990) could isolate the organism from $8 \%$ of fried fish whereas Moussa et al. (1992) reported an incidence of $26.6 \%$ in ready -to- eat fish. Besides, Rahmati et al. (2008) were able to isolate C.perfringens from $4.9 \%$ of raw and processed seafood.
C.perfringens spores can reach fish in their water habitat from surface of equipment and utensils used for processing and preparation or from workers, numbers greater than $10^{6}$ are necessary to cause illness, (Bryan, 1980).

Listeria spp. were recovered from the examined raw, grilled and fried fish samples with an incidence of 26.7, 16.7 and $10 \%$, respectively as shown in Table 6 L.monocytogenes was identified and constituted 10, 6.7 and $3.3 \%$ of the examined samples respectively.

The percentages of Listeria spp. in raw fish in this study was lower than that recorded by Ronda and Thaker (1992) (35\%) and Ebrahim and Thabet (2007) (53\%). On the other hand, the incidence of Listeria monocytogenes in the same product was nearly agreed with that results obtained by Mena et al. (2003) (12\%), Ibrahim and Hassan (2006) (9.3\%) and Wong et al. (1990) (10.5\%) while Weagant et al. (1998) recoded $26 \%$ L. monocytogenes of greatest concern from public health point of view.

Dalton et al. (2004) found that the most frequently implicated vehicles in 17.3 out breaks were seafood and L. monocytogenes caused $40 \%$ of the deaths.

From the summarized results given in Table 6 it is evident that Aeromonas spp. Could be detected in $73.3 \%$ of the examined raw fish samples where the identified starins were A.hydrophila (40\%), A.caviae (23.3\%) and A.sorbia (10\%).

On the other hand, 40 and $30 \%$ of the examined grilled and fried fish samples were positive for Aeromonas spp. The most prevalent strain was A.hydrophila (20 and $10 \%)$, followed by $A$. caviae (13.3 and $16.7 \%$ ) and A.sorbia (6.7 and 3.3\%).

However many investigators reported the isolation of different Aeromonas strains in variant percentages from raw and ready -toeat fish examined as Gobat and Jainmi (1992) Henin (1995) Abd El-Daym (1999), Bastawrows and Mohamed (1999), Mahmoud (1999), Ammar (2001), Nasser (2005) and Hamdy et al. (2009).

Salmonellae failed to be recoverd from any of the examined fish samples either raw or 
ready-to-eat fish, this results agreed the results obtained by Eldaly and Ibrahim (1987) and Hefnawy (1990) who couldn't isolate salmonellae from raw, or read to eat fish while Yousef et al. (1985) and Heinitiz et al. (1999), succeeded to isolate salmonellae from raw fish.

In conclusion, the present results revealed that fish may become contaminated with any of the foodborne pathogens where the level of contamination depends on the initial contamination and the opportunities for growth and/or survival processing and preparation of fish. Therefore, strict hygienic measures should be recommented to avoid contamination with these microorganisms: proper hand washing and disinfection, keeping raw and processed products, separated and implement handling and packaging practices that will limit the possibility of processed products becoming contaminated.

\section{REFERENCES}

Abd El-Daym, W.F.A. (1999): Microbiological aspects of smoked fishes at retail outlets. Master D. Thesis, Vet. Med.J. Sci. (Meat Hygiene) Zagazig Univ.

Abd El-Rahman, H.; Eisa, I.A.M. and Yassien, M.A. (1989): Occurrence of Clostridium perfringens in fish and mollusks. Assiut Vet. Med., 21 (42): 8083.

Abdel-Galil, Y.; El-Daly, E. and Mansour, N. (1988): Enteric organisms prevalent in market fish with special reference to E.coli. Bull. High. Inst. Publ. Hlth. 181123-1229.

Adesiyun, A.A. (1983): Prevalence and characteristics of staphylococci from five ready to eat predicts in Nigeria. Nigerian Food J.1 Cited by Adesiyun (1984).

Ahmed, M.Sh.; Zaitoun, A.M. and Ali, H.S. (1991): Motile Aeromonas septicaemia (MAS) in Mormyrus Kannume at Assiut Gevernorate. Assiut Vet. Med. J., 25: 145-150.

Ammar, M.A.M. (2001): Sanitary assessment of some common fresh water fish in
Assiut. M.V.Sc. Thesis. Fac. Vet. Med., Assiut Univ.

Angeloti, R.; Hall, H.E.; Foster, M.J. and Lewis, K.H. (1967): Quantization of Clostridium perfringens in food. Appl. Microbial. 10: 193-199.

AOAC: Association official analytical chemists (1990): Official Methods of Analysis of the association of Official Analytical Chemists. $15^{\text {th }}$ Ed. Inc. USA. AOAC.

APHA "American Public Helath Association" (1992): Compedium of Mothods for the Microbiological Examination of Foods $3^{\text {rd }}$ Ed. Washington, D. C. USA. APHA.

Bastawrows, A.E. and Mohammed, A.A. (1999): $\quad$ Some microbiological investigation on Aeromonas hydrophila in Oreochromis niloticus and Clarias lazera in Assiut Governorate. Assiut Vet. Med., J. 40 (80): 107-209.

Bloomfield, S.F. (2003): Home Hygiene, a risk approach, Inter. National Journal of Hygiene and Environmental Health. 2006: 1-8.

Bryan, F.L. (1980): Epidemiology of foodborne diseases transmitted by fish, shellfish and marine crustaceans in the United States, 1970-1978. J. Food Port., 43 (11): 859-867.

Chen, Y.H.; Jackson, K.M.; Chea, F.P. and Schafftener, D.W. (2001): Quantification and variability analysis of bacterial cross contamination rates in common food service tasks. J. Food Prot. 64: 72-80.

Dalton, C.B.; Gregory, J.; Krik, M.D.; Stafford, R.J.; Giveny, R.; Kraa, E. and Gould, D. (2004): Foodborne disease outbreaks in Asutalia 1995-2000. Commun-Dis intell., 28 (2): 211-224.

Ebraheem, L.M. and Thabet, M.H. (2007): Incidence of Listeria monocytogenes in frozen beef, poultry and fish in Assiut city. Assiut Vet. Med. J., 53, 113: 102110.

Eldaly, E. and Ibrabhim, A. (1987): Sanitary condition of ready to eat fishes. Alex. J. Vet. Sci., 3 (1): 101-109.

El-Gohary, A.H. and Samaha, H.A. (1992): The zoonotic importance of some 
bacterial and fungal pathogens isolated from fish at Alexandria Governorate. Proc. $5^{\text {th }}$ Sci. Cong. Fac. Vet. Med. Assiut Univ. 8-10 November, AssiutEgypt.

El-Sayed, M.F. (1991): Comparative studies on the keeping quality of some Nile and farm fishes. M.V. Sc. Thesis, Fac. Vet. Med., Alex. Univ.

FAO (1992): Manual of food quality control 4 Rev. 1 Microbiological analysis. (Andrews, W. Edit.) FAO food and nutrition paper No. 14/4 Rev.1.

Farouk, M. (1989): Microbiological evaluation of some fishes in rural markets. Ph. D. Thesis, Fac., Vet. Med., Alex. Univ.

Feingold, S.M. and Martin, W.J. (1982): Bailey and Scott Diagnostic Microbiology $6^{\text {th }}$ ed. C.U. Mosby Co. st. Louis, Toronto, London.

Gobat, P.F. and Jammi, F. (1992): Occurrence of Aeromenas spp. in poultry and fish products. Proceeding of $3^{\text {rd }}$ World Congress, Foodborne Infection and Intoxication. Berlin, pp. 1100 .

Grey, M.L. and Killinger, A.M. (1966): Listeria monocytogenes and listeric infection. Bacteriol. Rev. 30: 309-382.

Hafez, A.E. (1989): Prevalence of spoilage of fish. In Essays in Agriculture and Food Microbiology. Cited after Hassan Naglaa.

Hamdy, H.E.; Ahmed, M.M. and Nabil, H.M. (2009): Incidence of Aeromonas Hydrophila in fresh water fish (Til apia, Niolticus) and ready -to-eat hried fish in Assiut City. Assiut. Vet. Med. J. Vol. 56 (124): 57-66.

Hassan Naglaa, S. (1998): Studies on quality of frozen fish. Ph. D. Thesis Fac. Vet. Med. Beni-suef University.

Hefnawy, Y. (1990): Microbiological quality of ready-to-eat fried fish. Assiut Vet. Med. J., 22 (44) 116-121.

Heinitz, M.I.; Ruble, R.D.; Wagher, D.E. and Tatini, S.R.C. (1999): Incidence of Salmonella in fish and seafood. U.S. Food and Drug Administration, Minneapolis, Minnesota 55401-1999,
USA.

Henin, A.Y. (1995): Studies on motile Aeromonas species in fresh and frozen imported fish. Beni. Suef. Vet. Med., Res. 5 (2): 295-302.

Howgate, P. (1985): The self-life of fish products. J. Sci. Food Agric. 36 (2) 12: 126-127.

Huss, H.H. (1995): Quality and quality changes in fresh fish. Food Agriculture Organization (FAO), Fisheries Technical Paper 348. Rome: FAO.

Huss, H.H.; Reilly, A. and Emburak, P.K.B. (2000): Prevention and control of hazards in seafood. Food control 11: 149-156.

Ibrahim, H.S. and Hassan, H.F. (2006): Contamination of some local fish with listeria monocytogenes and studying its characterization and control. Assiut Vet. Med. J. 52: 109-127.

Kirby, R.M.; Bartram, B. and Carr, R. (2003): Water in food production and processing- Quality and quality concerns. Food Control. 14: 283-294.

Mahmoud, Y.E.A. (1999): Quality monitoring of some farm farm fish marketed in kafr El-Sheikh Governorate Assiut Vet. Med., J., 41 (82): 152-161.

Mena, C.; Almeida, G.; Carneiro, L.; Teixeria, P.; Hogg, T. and Gibbs, P.A. (2004): Incidence of listeria monocytogenes in different food products commercialized in fortygal. Food Microbial, 21: 213-216.

Montville, R.; chen, Y. and Schaffner, D.W. (2001): Determination of bacterial cross contamination rates from hand to food through algove burrier. J. Food Prot. 64: 845-849.

Montville, R.; Chen, Y. and Schaffner, D.W. (2002): Risk assessment of hard washing efficacy using literature and experimental data. International J. of Microbial. 73: 305-313.

Morshidy, A. and Hafez, A. (1986): Quality evaluation on frozen fish marketed in Zagazig City. Zagazig. J. Vet. Sci. 2: 14-17.

Morshidy, A.M.A. (1992 b): Food poisoning microorganisms in fishes of Manzala 
lake. Zag. Vet. Med. J. 20 (5): 709-712.

Morshidy, A.M.A. (1992a): Hygienic studies on fishes of Manzala lake, Zag. Vet. Med., J. 20 (5): 701-704.

Moussa, M.M.; Samaha, I. and Edaly, E. (1992): Occurrence of certain food poisoning organisms in some ready -toeat foods. Egypt J. Appril Sci., 7 (2): 21-25.

Mutkoski, S.A. and Schurer, S.L. (1981): Meat and Fish Management., PP 131, Wadsworth Inc., Belmont, California.

Naser, G.N. (1991): Occurrence of some food poisoning microorganisms in natural and farm fishes. M.V.Sc. Thesis. Fac. Vet. Med., Alex. Univ.

Nasser, M.M.M. (2005): Prevalnce of Aeromonas hydrophila in some types of Nasser lake fishes. M.V. Sc. Thesis. Fac. Vet. Med., Assiut Univ.

National Academy of Sciences (1985): An Evaluation of the Role of Microbiological Criteria for Foods and Food Ingredients. National Academy Press, Washington, D.C.

Nickelson, R. and Finne, G. (1984): Fish, crustaceans and precooked seafoods. In Compendium of Methods for the Microbiological Examination of Foods. Speck, M. L. (ed)., $2^{\text {nd }}$ Ed. American Public health Association, Washington, D. C., P. 573-589.

Okrend, J.G.; Rose, B.B. and Bennett, B. (1987): Incidence and toxigenicity of Aeromonas spp. In retail poultry, beef and pork J. Food Prot. 50: 509-513.

Rahmti, T. and Labby, R. (2008): Levels and toxigenicity of Bacillus cereus and Clostridium prefringens from retail seafood J. Food Prot., 71, 6: 1178-1185.

Reij, M.W.; Den Aantrekker, E.D. and ILSI Europe Risk Analysis in microbiology Task Force (2003): Recontamination as a source of pathogens in processed foods international J. Food Microb. Artide in press.

Ronda, M.D. and Thakar, R.P. (1992): Listeria in seafoods. J. Food Prot., 55.,
(12): 1009-1015.

Scott, D.; Fletcher, G.C.; Charles, J.C. and Wang, R.J. (1992): Spoilage changes in the deep-water fish smooth Oreodory during storage in ice. International $\mathrm{J}$. Food Sci. Technol. 27: 577-587.

Surkiewicz, B.F.; Groomes, R.J. and Shelton, L.R. (1968): Bacteriological survey of the frozen prepared foods industry IV. Frozen breaded fish. Appl. Microbiol. Foods. 16: 147-150.

Thabet, F.M. (1972): Studies on the spoilage for some fish species. Ph. D. Thesis. Fac. Agric. Ain. Shams Univ.

Varnam, A.H. and Evans, M.G. (1991): Yersinia In Foodborne Pathogens.Wolfe Publishing ltd., London, England.

Venugopal, V. (2002): Biosensors in fish production and quality control. Biosensors and Bioelectronics. 17: 147-157.

Weagant, S.D.; Sado, P.N.; Colbum, K.G.; Torkelson, J.D.; Stanly, F.A.; Krane, M.H.; Shields, S.C. and Thayer, C.F. (1998): The incidence of Listeria spp. in frozen seafood. J. Food Prot. (S1): 655-667.

Wong, II, Ch.; Wel. Liang, Ch. and ShiuJung, L. (1990): Incidence and characterization of Listeria monocytogenes in foods available in Taiwan. Appl. Enviorn. Microbiol. (56): 3101-3104.

Yousef, H.; El-Timaway, A.M. and Ahmed, S.H. (1981): The role of aerobic intestinal pathogens of freshwater fish in transmission of human disease. Assiut. Med. J. 5 (1): 1-8.

Yousef, H.; EL-Timaway, A.M. and Hefnawy, $Y$. (1985): Microbial quality of freshwater fish. Assiut Vet. Med., J. 14 (28): 109-114. 